\title{
DEVELOPMENT OF THE REAL-TIME PCR METHODOLOGY FOR TESTING MYCOTOXIGENIC MICROORGANISMS IN GRAPE MARC
}

\author{
Rodica Sturza ${ }^{1}$, ORCID ID: 0000-0002-2412-5874, \\ Valentin Mitin2, ORCID ID: 0000-0001-9328-9672, \\ Irina Mitina², ORCID ID: 0000-0002-1550-6739, \\ Dan Zgardan ${ }^{1 *}$, ORCID: 0000-0002-1296-0864, \\ Antoanela Patras ${ }^{3}$, ORCID ID: 0000-0002-4054-4884, \\ Emilia Behta ${ }^{1,4}$, ORCID ID: 0000-0001-8519-9714 \\ ${ }^{1}$ Technical University of Moldova, 168 Stefan cel Mare Blvd., Chisinau, RM \\ ${ }^{2}$ Institute of Genetics, Physiology and Plant Protection, 20 Pădurilor st., Chisinau, RM \\ 3"Ion Ionescu de la Brad" Iasi University of Life Sciences, 3 Mihail Sadoveanu Aleea, IaşiRomania \\ 4"Nicolae Testemitanu" State University of Medicine and Pharmacy, 165 Stefan cel Mare Bd., Chisinau, RM \\ *Corresponding author: Dan Zgardan, dan.zgardan@enl.utm.md
}

Received: 07. 23. 2021

Accepted: 08. 28. 2021

\begin{abstract}
Agro-industrial waste management is an important problem of modern society as agriculture and food industry are important sources of waste. Wine production generates a considerable amount of winemaking waste (grape marc). Grape marc can be a source of natural dyes, antioxidants and could have various applications, if it is confirmed that it does not contain technogenic contaminants or unwanted microorganisms, for example, producers of mycotoxins. The paper developed the Real -Time Polymerase Chain Reaction (Real-Time $\mathrm{PCR})$ methodology for testing the presence of potentially mycotoxogenic fungal species capable of producing ochratoxin A (OTA), which could be applied before grape marc processing. Based on the non-ribosomal peptide sequence of OTA, involved in ochratoxin biosynthesis, the primers have been developed for the detection of microorganisms potentially capable of producing ochratoxin A.
\end{abstract}

Keywords: Mycotoxin, OTA, Real-Time PCR, grape marc, Aspergillus, Penicillium.

\section{Introduction}

Grape marc is a by-product of the vinification process, which constitutes approximately $20-30 \%$ of the mass of processed grapes [1]. The rich content of bioactive substances in the composition of grape marc, derived from grape skin, remaining pulp, seeds and stems is an opportunity for its use in the pharmaceutical industry, cosmetics and, especially, in the food industry $[2,3,4]$. The rich content of dietary fiber, up to $85 \%$ and polyphenols, up to $70 \%[5,6]$, increased antioxidant activity [7] are important arguments in favor of capitalizing on this byproduct $[8,9]$. The recovery of by-products of vinification is also an important issue for the management of agro-industrial waste $[10,11]$. 
Grape marc is usually stored, used as fertilizer or for animal nutrition [12]. The storage and spread of grape mark in the environment can cause damage to the environment, lead to water pollution and, finally, create inconvenience to nearby towns, because due to low $\mathrm{pH}$ and the presence of tannins, biodegradation of this byproduct occurs very slowly [13]. The use of grape marc for animal feed is not reasonable, because it is poor in nutrients and the tannins are difficult to digest $[14,15]$.

At the same time, the recovery of bioactive components from grape marc requires its rigorous control, because, especially in years with precipitation during the ripening period of grapes they can be contaminated with mycotoxins [16]. Mycotoxigenic molds, capable of colonizing grapes, especially affect the skin of the berries, so there are risks that after the vinification process, they remain in the marc. Thus, there are risks of contamination of grape marc, derived products and grape marc extracts with mycotoxins, especially when marc is not processed immediately after the vinification process [17].

In order to ensure the innocuousness of the products obtained from grape marc, it is necessary to check the presence of mycotoxinogenic microorganisms before processing the pomace. Previous research has shown that the Real-Time PCR methodology can be successfully applied for the analysis and quantification of mycotoxigenic fungi in maize [18], as well as for the detection of Brettanomyces/Dekkera in wines [19]. The purpose of this research was to develop a rapid method real-time PCR to verify the presence of microorganisms capable of producing mycotoxins in grape marc.

\section{Materials And Methods}

Grape marc samples were collected from different geographical zones. Table 1 shows the details of the samples used in this study.

Table 1

Grape marc samples used in this study*

\begin{tabular}{cccc}
\hline Sample name & Sample type & Variety of grape/wheat & Sample origin \\
\hline A2 & Grape marc & Feteasca Neagra & Speia, Anenii-Noi \\
\hline A3 & Grape marc & Cabernet-Sauvignon & Popeasca, Stefan-Voda \\
\hline A4 & Grape marc & Cabernet-Sauvignon & Cojusna, Straseni \\
\hline A6 & Grape marc & Cabernet-Sauvignon & Pleseni, Cantemir \\
\hline A8 & Grape marc & Merlot & Salcuta, Causeni \\
\hline A9 & Grape marc & Cabernet-Sauvignon & Abaclia, Basarabeasca \\
\hline A10 & Grape marc & Cabernet-Sauvignon & Tigheci, Leova \\
\hline A11 & Grape marc & Pinot Noir & Taraclia \\
\hline B12 & Wheat grain & $\begin{array}{c}\text { Wheat with visual signs } \\
\text { of fungal infection }\end{array}$ & Chisinau, IGPPP* \\
& &
\end{tabular}

*Institute of Genetics, Physiology and Plant Protection

\section{Isolation of the DNA}

Total deoxyribonucleic acid (DNA) was extracted from wine using SDS-based DNA extraction methods [20] with some modifications. The procedure was carried at the room temperature. Briefly, $0.5 \mathrm{~g}$ of grape marc was homogenized to fine powder with $0.5 \mathrm{~g}$ of

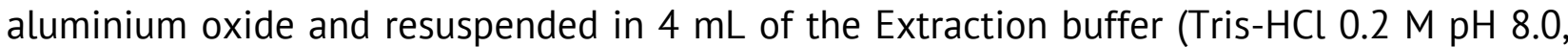
$\mathrm{NaCl} 0.25 \mathrm{M}, \mathrm{Na}_{2}$ EDTA $0.025 \mathrm{M}$, SDS $5 \% \mathrm{w} / \mathrm{v}$ ) and heated at $65^{\circ} \mathrm{C}$ for 1 hour. After 10 minute centrifugation at $10000 \mathrm{~min}^{-1}$ the supernatant was transferred to a fresh tube, mixed with an 
equal volume of isopropanol and incubated at $-20{ }^{\circ} \mathrm{C}$ for 30 minutes. The samples were centrifuged, the pellet washed with $70 \%$ ethanol, air dried and dissolved in $100 \mu \mathrm{L}$ of water; $2 \mu \mathrm{L}$ of the resulting DNA solution was used per polymerase chain reaction (PCR). The qualitative and quantitative verification of the isolated DNA was made by spectrophotometric analyses.

\section{Polymerase Chain Reaction Amplifications}

The Real-Time PCR allows precise quantification of specific nucleic acids in a complex solution by fluorescent detection of labeled PCR products. In a Real Time PCR, a positive reaction is detected by accumulation of a fluorescent signal. For the experiments, we used SYBR Green I nonspecific dye as the fluorescent agent. The quantification cycle (Cq) represents the number of cycles required for the fluorescent signal to cross the threshold (i.e., to pass the background level). Cq levels are inversely proportional to the amount of target nucleic acid in the sample. The lower the $\mathrm{Cq}$ level the higher is the concentration of target nucleic acid in the sample. We used 40 cycles of amplification [21].

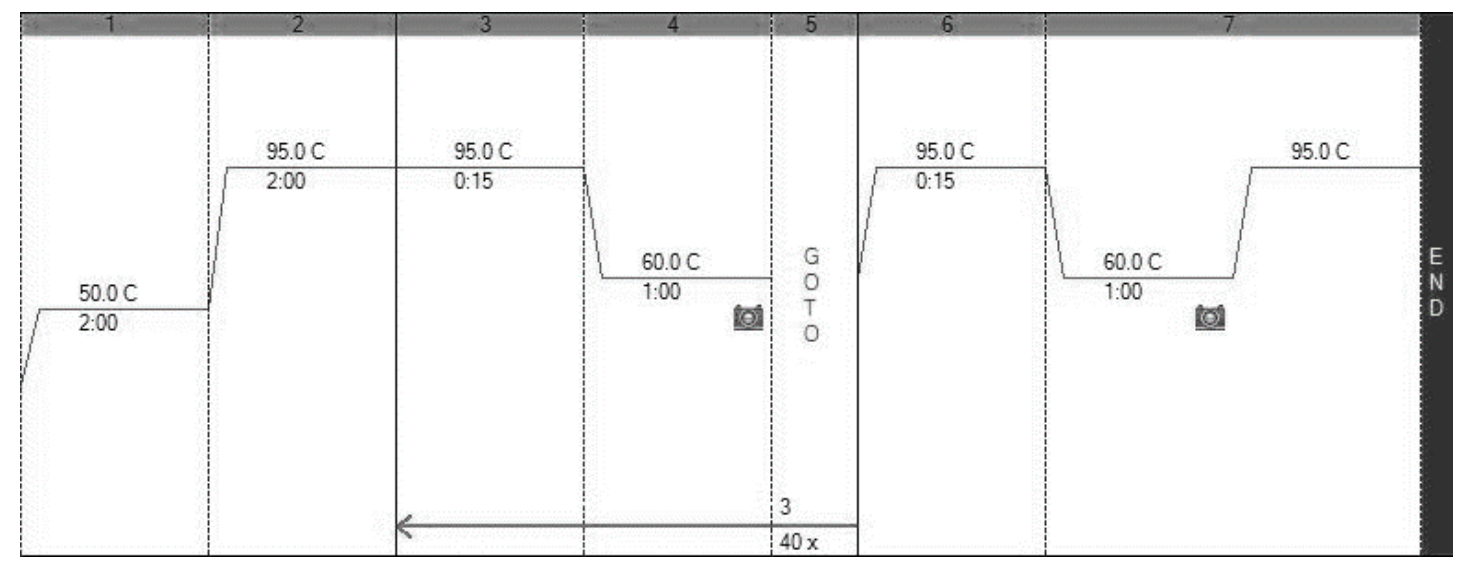

Figure 1. Temperature cycling conditions

In our research Real-Time PCR has been done at Real-Time PCR Detection Systems CFX96 TouchTM BIORAD. PCR conditions were as recommended by SybrGreen producer (Applied Biosystems) - initial incubation at $50{ }^{\circ} \mathrm{C}$ for 2 minutes, initial denaturation at $95^{\circ} \mathrm{C}$ for 2 minutes, and alternation at $95^{\circ} \mathrm{C}$ for 15 seconds and $60^{\circ} \mathrm{C}$ for 1 minute for 40 cycles. For melting curve construction, samples were heated at $95^{\circ} \mathrm{C}$ for 15 seconds, then incubated at $60^{\circ} \mathrm{C}$ for 1 minute $\left(1.6^{\circ} \mathrm{C} / \mathrm{s}\right.$ ramp rate), then heated at $95^{\circ} \mathrm{C}$ for 15 seconds $\left(0.15^{\circ} \mathrm{C} / \mathrm{s} \mathrm{ramp}\right.$ rate). Cycling conditions are shown in Figure 1 . The detection was done at SYBR channel.

\section{Results and discussion}

During this work, two pairs of primers based on Vitis vinifera 26S ribosomal RNA gene sequence were developed. Using these primers in PCR reaction can confirm that the extracted DNA is of PCR quality and is free of PCR inhibitors. Besides, these primers allow normalizing the amount of the input DNA in PCR reaction for estimation of the amount of pathogen DNA relative to plant DNA in different samples.

Though for primer design Vitis vinifera 26S ribosomal RNA gene sequence was used, they can recognize a vast number of eukaryotic organisms according to the BLAST analysis. Table 2 shows names, sequences and characteristics of the primers used for detection of eukaryotic DNA in the sample.

The gene bank accession used as a template was DQ667962.1 Vitis vinifera 265 ribosomal RNA gene, partial sequence. 
Table 2

Primers used for detection of eukaryotic DNA in the sample

\begin{tabular}{|c|c|c|c|c|c|c|c|c|}
\hline 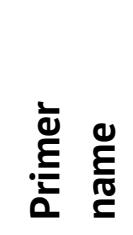 & 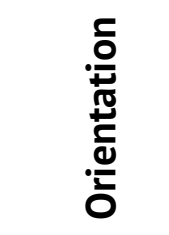 & 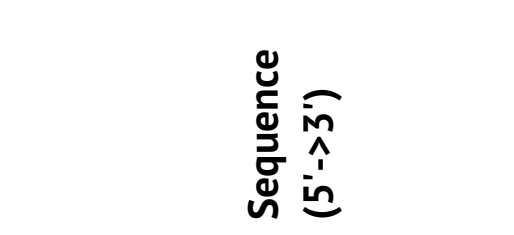 & 袁 & $\underline{\boldsymbol{E}}$ & 엄 & $\stackrel{4}{\mathcal{J}}$ & 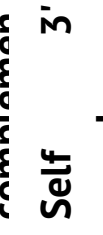 & 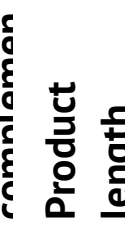 \\
\hline P183 & $\begin{array}{l}\text { Forward } \\
\text { primer }\end{array}$ & CGGGTAAACGGCGGGAGTAA & 20 & 62.22 & 60.00 & 3 & 1 & \multirow{2}{*}{131} \\
\hline P184 & $\begin{array}{l}\text { Reverse } \\
\text { primer }\end{array}$ & TGGCTGTGGTTTCGCTGGAT & 20 & 62.41 & 55.00 & 2 & 2 & \\
\hline P185 & $\begin{array}{l}\text { Forward } \\
\text { primer }\end{array}$ & CCGGAAACGGCGAAAGTGAA & 20 & 61.50 & 55.00 & 4 & 0 & \multirow{2}{*}{150} \\
\hline P186 & $\begin{array}{l}\text { Reverse } \\
\text { primer }\end{array}$ & GCCAAACTCCCCACCTGACA & 20 & 62.35 & 60.00 & 3 & 3 & \\
\hline
\end{tabular}

Primers for detection of the potential producers of OTA were designed based on the sequence of OTA non-ribosomal peptide synthetase gene. This is a gene involved in OTA biosynthesis. These primers can recognize the following pathogens containing OTA nonribosomal peptide synthetase gene in their genome, and thus potentially capable of producing OTA: Aspergillus nidulans, Aspergillus tubingensis, Aspergillus tamarii, Aspergillus niger, Aspergillus ochraceus, Aspergillus carbonarius, Penicillium viridicatum, Penicillium carneum, Penicillium aurantiogriseum, Penicillium melanoconidium, Penicillium nordicum, Penicillium verrucosum. Table 3 shows primer names, sequences and characteristics.

Table 3

Primers used for detection of potential OTA producers

\begin{tabular}{|c|c|c|c|c|c|c|c|c|}
\hline 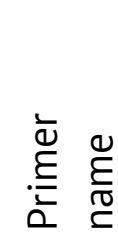 & 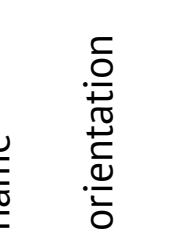 & 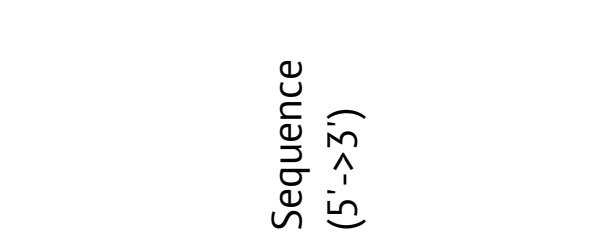 & 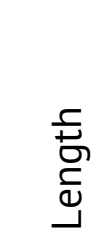 & $\underline{\varepsilon}$ & نِّ & $\frac{4}{\sim}$ & 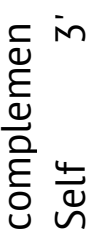 & 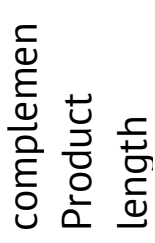 \\
\hline P71 & $\begin{array}{l}\text { Forward } \\
\text { primer }\end{array}$ & GGCTTCGTGTTGTCCCTTCT & 20 & 60.25 & 55.00 & 2 & 0 & \multirow[b]{2}{*}{97} \\
\hline P72 & $\begin{array}{l}\text { Reverse } \\
\text { primer }\end{array}$ & GTCCATTCTCGACGTGTTCCA & 21 & 60.34 & 52.38 & 4 & 1 & \\
\hline P73 & $\begin{array}{l}\text { Forward } \\
\text { primer }\end{array}$ & CATGGTCGTTTGGACGATGTGA & 22 & 61.18 & 50.00 & 5 & 1 & \multirow{2}{*}{155} \\
\hline P74 & $\begin{array}{l}\text { Reverse } \\
\text { primer }\end{array}$ & CAGCTCGGCTCGATCAACAG & 20 & 61.14 & 60.00 & 4 & 2 & \\
\hline P75 & $\begin{array}{l}\text { Forward } \\
\text { primer }\end{array}$ & GCCGCAAGGTCAGTGAATGT & 20 & 61.24 & 55.00 & 5 & 1 & \multirow{2}{*}{119} \\
\hline P76 & $\begin{array}{l}\text { Reverse } \\
\text { primer }\end{array}$ & TGTGGGACTCCACTCAAAGTAAGA & 24 & 61.18 & 45.83 & 5 & 1 & \\
\hline P77 & $\begin{array}{l}\text { Forward } \\
\text { primer }\end{array}$ & CCGCAAGGTCAGTGAATGTACTC & 23 & 61.47 & 52.17 & 5 & 2 & \multirow{2}{*}{144} \\
\hline P78 & $\begin{array}{l}\text { Reverse } \\
\text { primer }\end{array}$ & TCGACGTGTTCCATTTCAATACCA & 24 & 60.80 & 41.67 & 4 & 0 & \\
\hline
\end{tabular}


The gene bank accession used as a template was GenBank: JN097804.1 Aspergillus ochraceus strain CBS 589.68 OTA non-ribosomal peptide synthetase gene, partial cds.

Next, the grape marc DNA samples were analyzed by real-time PCR using the designed primers. In this study, we analyzed 8 grape marc samples of different grape varieties from different zones (Table 1, Materials and Methods). As a positive control for the primers, we used wheat with visible signs of fungal infection, previously shown to contain OTA nonribosomal peptide synthetase gene. First, the amplificability of DNA from grape marc was tested, using primer pairs p. 183 - 184 and p. 185 - 186. Table 4 shows the results of realtime PCR analysis with primer pair p. $183-184$.

Table 4

\section{Real-Time PCR data analysis for primer pair P183-P184}

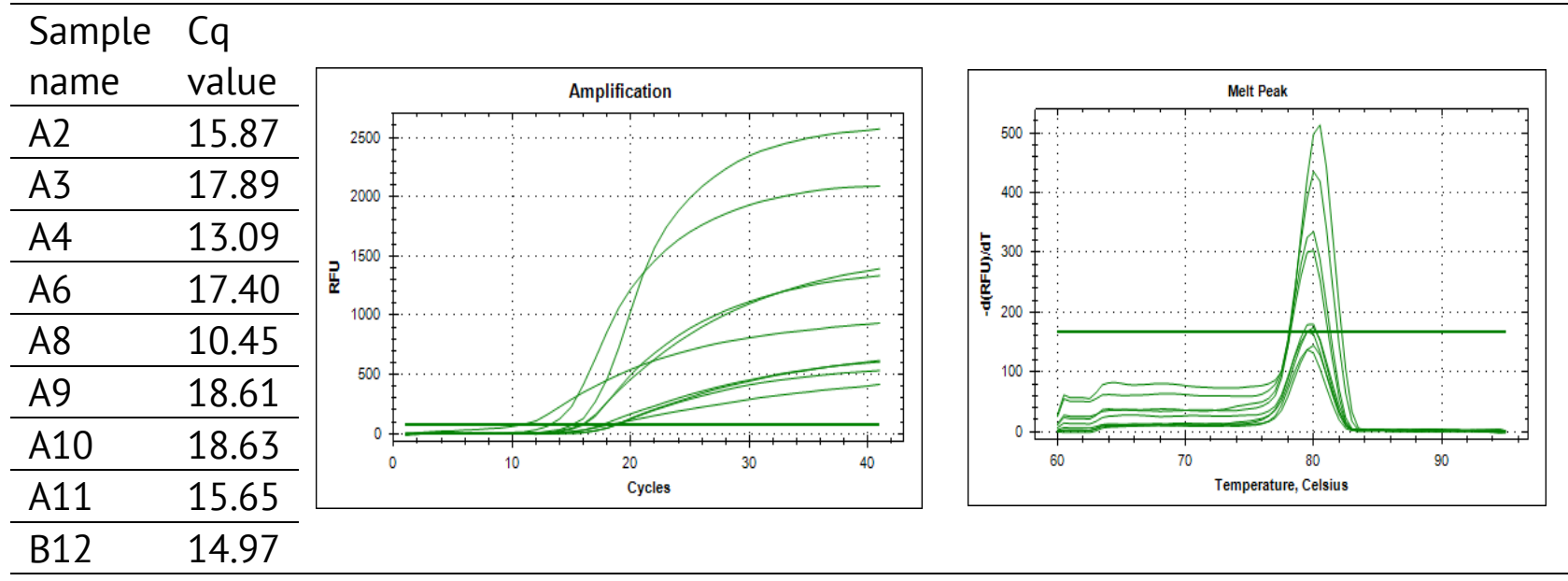

These data show that every sample had the DNA template that could be amplified by this primer pair. The Cq values vary from 10.45 in A8 sample to 18.63 in A10 sample. The melting curve shows a single well pronounced peak with similar melt temperature for all samples. This indicates that the amplified fragment is uniform. Table 5 shows the results of real-time PCR analysis with primer pair p. 185 - 186. In this case, the template DNA could as well be amplified by this primer pair. The Cq values vary from 12.97 in A8 sample to 33.46 in B12 sample, table 5 . High Cq value for the wheat DNA sample means that the threshold fluorescence level is reached later in this sample. This can be explained by either low DNA content or lower primer affinity to this template.

Table 5

\section{Real-Time PCR data analysis for primer pair P185-P186}

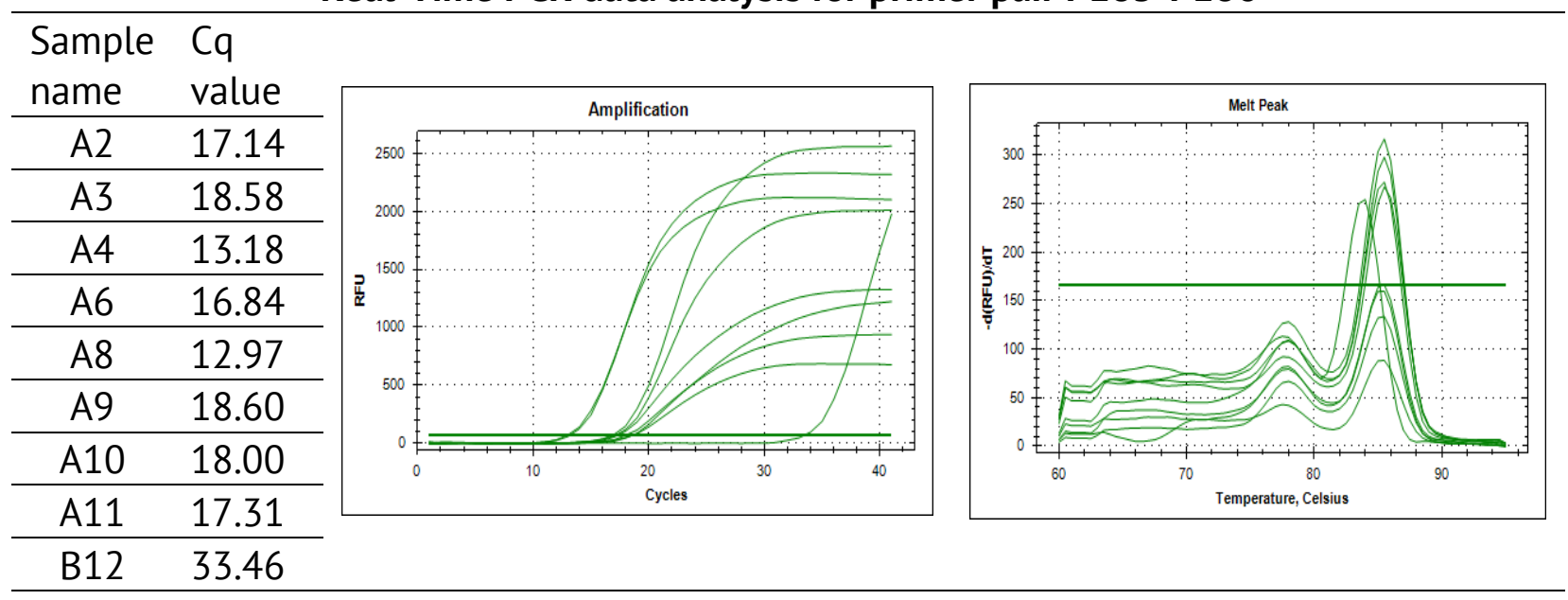


Since the other primer pair p185-186, did not produce such a low Cq value for B12 sample, and since the primers were designed using Vitis vinifera gene as a template, one can assume that the higher Cq value is caused by lower affinity of the primer pair p. 185 - 186 to the wheat DNA. Another evidence favoring this explanation is a slightly different melting temperature for the melting peak of B12 (wheat) sample. Anyways, both primer pairs showed amplification in all analyzed samples, confirming that the analyzed DNA is of PCR quality.

Next, we analyzed the same samples using primers to ochratoxin A non-ribosomal peptide synthetase gene to detect potential OTA producer in the grape marc. Table 6 shows the results of Real-Time PCR analysis with primer pair p71-p72.

Table 6

Real-Time PCR data analysis for primer pair P71-P72

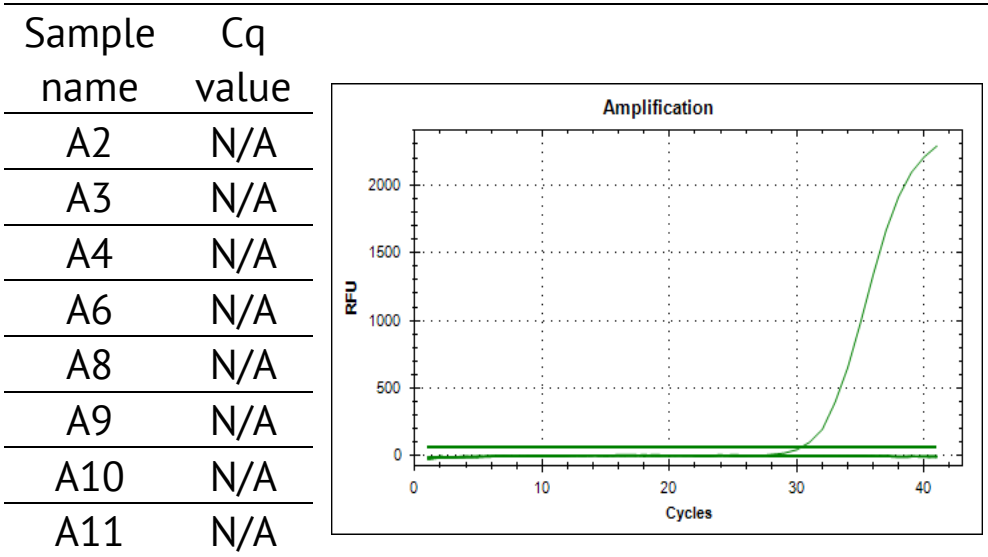

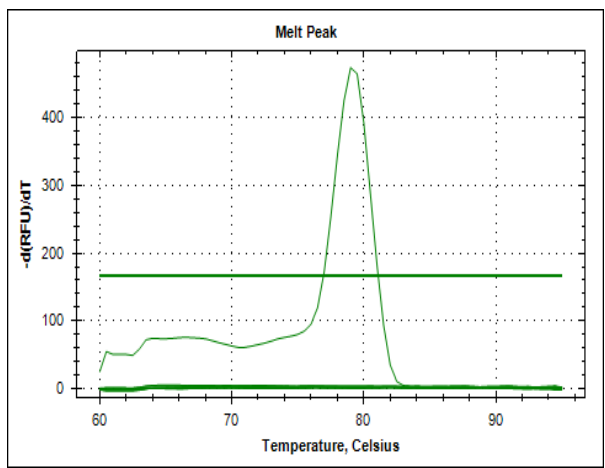

B12 30.43

As one can see from the Table 6, no signal was obtained for either grape marc sample. The only positive signal obtained in this experiment was for B12 (wheat) control, with the $\mathrm{Cq}$ value 30.43 . The melt curve shows a single well pronounced peak indicating that a single fragment is amplified in the PCR reaction.

Similar results were obtained for the other 3 primer pairs (p. $73-74$, p. $75-76$ and p. 77 - 78). Table 7 shows the Cq values obtained by different primer pairs designed to OTA non-ribosomal peptide synthetase gene.

Table 7

The Cq values for different primer pairs designed to OTA non-ribosomal peptide synthetase gene

\begin{tabular}{lllll}
\hline \multirow{2}{*}{$\begin{array}{llll}\text { Sample } \\
\text { name }\end{array}$} & \multicolumn{4}{l}{ Cq value for primer pairs } \\
\cline { 2 - 5 } A2 & P71-72 & P73-74 & P75-76 & P77-78 \\
\cline { 2 - 5 } A3 & N/A & N/A & N/A & N/A \\
A4 & N/A & N/A & N/A & N/A \\
A6 & N/A & N/A & N/A & N/A \\
A8 & N/A & N/A & N/A & N/A \\
A9 & N/A & N/A & N/A & N/A \\
A10 & N/A & N/A & N/A & N/A \\
A11 & N/A & N/A & N/A & N/A \\
B12 & 30.43 & 30.53 & 31.09 & 30.70 \\
\hline
\end{tabular}


As one can see, no grape marc sample was positive for the OTA non-ribosomal peptide synthetase gene, involved in OTA synthesis, though every primer pair recognized this gene in the positive control wheat sample. Thus, though the grape marc DNA was of a sufficient quality for PCR reaction, no DNA belonging to potential OTA producers from genera Aspergillus and Penicillium was detected. This can speak in favor of grape marc biological safety for further use.

\section{Conclusions}

1. Based on the sequence of OTA non-ribosomal peptide synthetase, involved in ochratoxin biosynthesis, four pairs of primers for detection of the microorganisms potentially capable of producing OTA were developed.

2. For internal control of DNA quality, two pairs of primers capable of recognizing eukaryotic DNA, using the sequence of Vitis vinifera 265 ribosomal RNA gene as a template were developed.

3. SDS-based method of DNA extraction was adapted for purifying the DNA from grape marc.

4. No microorganisms potentially capable of producing OTA were detected in the analyzed grape marc samples, which makes them suitable for further use.

5. The proposed Real-Time PCR method for verifying the presence of mycotoxigenic microorganisms in grape marc would avoid further contamination of grape marc, derived products and grape marc extracts, obtained from this by-product of vinification.

Acknowledgments: The authors would like to thank the Project 2SOFT/1.2/83 "INTELLIGENT VALORISATION OF AGRO-FOOD INDUSTRIAL WASTES (INTELWASTES)", funded by the European Union, within the program Cross border cooperation Romania Republic of Moldova 2014-2020.

\section{References}

1. Dwyer K., Hosseinian F., Rod M.R. The market potential of grape waste alternatives. In: Journal of Food Research, 2014, 3, 91.

2. Spinei A., Sturza R., Moșanu A., Zagnat M., Bordeniuc Gh. The use of anthocyanin extract obtained from wine products in the prevention of experimental dental caries. In: Romanian Journal of Dentistry, 2017, 20 (3), pp. $161-175$.

3. Antonic B., Jancikova S., Dordevic D., Tremlova B. Grape Pomace Valorization: A Systematic Review and MetaAnalysis. In: Foods, 2020, 9, p. 1627.

4. García-Lomillo J., González-Sanjosé M.L. Applications of wine pomace in the food industry: Approaches and functions. In: Comprehensive Reviews in Food Science and Food Safety, 2017, 16, pp. 3 - 22.

5. Quiles A., Campbell G. M., Struck S. et al. Fiber from fruit pomace: A review of applications in cereal-based products. In: Food Reviews International, 2018, 34 (2), pp. 162 - 181.

6. Sousa E.C., Uchoa-Thomaz A., Carioca J., Morais S., Lima A., Martins C., Alexandrino C., Ferreira P., Rodrigues A., Rodrigues S., et al. Chemical composition and bioactive compounds of grape pomace (Vitis vinifera L.), Benitaka variety, grown in the semiarid region of Northeast Brazil. In: Food Science and Technology, 2014, 34, pp. 135 - 142.

7. Cristea E., Sturza R., Jauregi P., Niculaua M., Ghendov-Moșanu A., Patras A. Influence of pH and ionic strength on the color parameters and antioxidant properties of an ethanolic red grape marc extract. In: Journal of Food Biochemistry, 2019, e12788.

8. Adámez J.D., Samino E.G., Sánchez E.V., González G.D. In vitro estimation of the antibacterial activity and antioxidant capacity of aqueous extracts from grape-seeds (Vitis vinifera L.). In: Food Control, 2012, 24, pp. $136-141$.

9. Peixoto C.M., Dias M.I., Alves M.J., Calhelha R.C., Barros L., Pinho S.P., Ferreira I.C. Grape pomace as a source of phenolic compounds and diverse bioactive properties. In: Food Chemistry, 2018, 253, pp. 132 - 138. 
10. Sadh P.K., Duhan S., Duhan J.S. Agro-industrial wastes and their utilization using solid state fermentation: a review. In: Bioresources and Bioprocessing, 2018, 5 (1).

11. Musteaţă Gr., Balanuţă A., Reşitca V. Filimon R.V., Băetu M., Patraș A. Capitalization of secondary wine products - an opportunity for the wine sector of Republic of Moldova and Romania. In: Journal of Social Sciences, 2021, 4(2), pp. 117 - 127.

12. Andelkovic M., Radovanovic B., Milenkovic-Andelkovic A., Radovanovic V., Zarubica A., Stojkovic N., Nikolic $V$. The determination of bioactive ingredients of grape pomace (Vranac variety) for potential use in food and pharmaceutical industries. In: Advanced Technologies, 2015, 4, pp. 32 - 36.

13. Bustamante M.A., Moral R., Paredes C., Pérez-Espinosa A., Moreno-Caselles J., Pérez-Murcia M.D. Agrochemical characterisation of the solid by-products and residues from the winery and distillery industry. In: Waste Management, 2008, 28, pp. 372 - 380.

14. Nistor E., Dobrei A., Bampidis V., Ciolac V. Grape pomace in sheep and dairy cows feeding. In: The Journal of Horticultural Science and Biotechnology, 2014, 18, pp. 146 - 150.

15. Abarghuei M., Rouzbehan Y., Alipour D. The influence of the grape pomace on the ruminal parameters of sheep. In: Livestock Science, 2010, 132 (1-3), pp. 73 - 79.

16. Sturza R., lazacovici O. Quantification of ochratoxin A in Moldavian wines. In: Scientific Study \& Research. Chemistry \& Chemical Engineering, Biotechnology, Food Industry, 2017, 18 (3), pp. 339 - 334.

17. Sturza R., Găină B., lonete E, Costinel D. Authenticity and harmlessness of uvological products. "MS Logo" Publishing House, Chisinau, 2017, 264 p. (In Romanian).

18. Mitina I., Mitin V., Tumanova L., Zgardan D., Sturza R. Detection and quantification of mycotoxigenic fungi in maize by real-time PCR. In: Journal of Engineering Science, 2020, 27(3), pp. 225-231.

19. Mitina I., Zgardan D., Sturza R., Scutaru lu. The methodological aspects of using real-time polymerase chain reaction (RT-PCR) in Brettanomyces/Dekkera detection. In: Journal of Engineering Science, 2019, 26 (2), pp. $117-125$.

20. ISO 21571:2005 Foodstuffs - Methods of analysis for the detection of genetically modified oganisms and derived products - Nucleic acid extraction. A.2 Preparation of PCR-quality DNA using polyvinyl-pyrrolidone (PVP)-based DNA extraction methods. Available: https://www.iso.org/standard/34616.html

21. Boistean A., Chirsanova A., Zgardan D., Mitina I., Gaina B. Methodological aspects of real-time PCR usage in acetobacter detection. In: Journal of Engineering Science, 2020, 3, pp. 232 - 238. 